\title{
Healing liturgy: The role of music and singing
}

Author:
Coenie J. Calitz'
Affiliation:
'Faculty of Theology,
North-West University,
South Africa
Corresponding author:
Coenie Calitz,
cjcalitz@gmail.com
Dates:
Received: 21 Apr. 2016
Accepted: 18 Apr. 2017
Published: 31 May 2017
How to cite this article:
Calitz, C.J., 2017, 'Healing
liturgy: The role of music and
singing', Verbum et Ecclesia
38(1), a1628. https://doi.org/
10.4102/ve.v38i1.1628
mobit phone or
mobile device
to read online.
Copyright:
C 2017. The Authors.
Licensee: AOSIS. This work
is licensed under the
Creative Commons
Attribution License.

Apart from all the other functions of liturgical singing and music, it also has a pastoral function or aim. Within the normal Sunday-to-Sunday liturgy, singing and music aims at promoting and restoring spiritual well-being. Within communities struck by disaster or grief, liturgical singing aims at healing people and processing their loss and ultimately promoting spiritual wellness by restoring or reshaping their picture of God. A brief look at liturgies in a lamenting congregation by means of an autoethnography illustrates the functional use of music and singing in the process of spiritual or emotional healing, thus illustrating the role of music in worship as an in-between experience: between laughter and lament.

Intradisciplinary and/or interdisciplinary implications: The article explores the role of music and singing in healing liturgy in a descriptive way, using ethnography and autoethnography to describe the process. Although the article refers to insights from pastoral therapy, it only makes suggestions for liturgy and in a lesser sense, hymnology.

\section{Introduction}

In a culture dominated by the visual and the verbal, the significance of music is perplexing, and is therefore underestimated. (Storr 1992:xii)

A few years ago a short video with the title 'The best coin ever spent' was released on the Internet (Wimp n.d.). A little girl donates some coins to a street musician and gets a surprise in return: a band and choir with 100 people from the Vallès Symphony Orchestra, the Lieder, Amics de l'Òpera and Coral Belles Arts choirs started playing 'Ode to joy' as part of a flash mob in a public space. For a moment everybody came to a standstill - carried away by the music. Somehow, for a few minutes, the world stood still and pain was forgotten. Storr (1992:90) rightly refers to the ability of music to lift the hearers above their reality. The belief in the ability of music is illustrated in church members' visits to hospitals to sing to the sick, as well as visits to houses for elderly people to sing to or with them hoping to heal and transform lives.

Within the contemporary movement (Horness 2004:102) church music and singing are often reduced to praise and worship (see Redman 2002:37-40). Hymnological studies, on the other hand, identify many more functions for liturgical singing - these include a pastoral function, which among other aims at healing individuals as well as a congregation. The pastoral function of liturgical singing is largely neglected and underestimated. This article aims at understanding the healing function of music and singing within the liturgy of the worship service. We start with a literature study on the pastoral function of music and singing in liturgy, as well as insights from pastoral therapy in order to understand the role of music in singing within liturgy. The literature study is followed by an autoethnographic description of a congregation in the process of loss and grief, with the aim of describing the role singing and music played in the healing process. The author of this article (Pastor B) was part of the grieving congregation, and the emotions, processes and liturgies are described from the viewpoint of the author by means of an autoethnographic study.

This study will thus combine a literature study (part 1) with an autoethnographic study (part 2). Although these two are separated for the purpose of the study, they are interlinked and as such part of one research process. The autoethnographic study (and methodology) will be described in the second part of the article.

\section{Literature study Liturgy of life versus liturgy of worship service}

Liturgy (from the term latreia) in broader context refers to the liturgy of life, while in narrower context it refers to the liturgy (order) of the worship service (Louw \& Nida 1989:9). Within this article, liturgy is used in the narrower context referring to the liturgy of the worship service. 
It includes all the words and acts of the worship service (Barnard 1981:52).

Liturgy supposes a strong relationship between day-to-day life and the liturgy of the worship service. Not only the larger narrative of the Bible but also the smaller narratives of dayto-day life (the story of the congregation) ought to be brought together within the worship service (Pieterse 2001:19-23). Cilliers (2009b:21) refers to the four liturgical tensions as an expression of the existential reality, namely between being and becoming, between time and space, between awe and expression and between laughter and lament. He then concludes that '[i]f liturgy (leitourgia) is also meant to be liturgy of life (liturgy on the street), then existentialia, like these, should surely be brought into view and into liturgical consideration' (Cilliers 2009b:21).

The liturgy of life and the realities of life ought to be reflected in the liturgy of the worship service, in such a way that liturgy is co-shaped by day-to-day life, and day-to-day life is co-shaped by liturgy. In this regard, Calitz (2011:22) remarks that liturgical singing is always closely connected to the context of the singing congregation. Just as the liturgy of the worship service ought to reflect the existentialia of the congregation and the church in broader context, so the music and singing must somehow reflect these. Selander (2001:202) illustrates that the function of church singing was often influenced or determined by context and time.

\section{Motives for liturgical singing}

The liturgy of the worship service has definite motives; these include a Scriptural motive, ecumenical motive, confessional motive, pastoral motive and reconciliation motive (Calitz 2011:74; Schelling 1989:16; Strydom 1991:182-311). Within the purpose of this study it is important to note that the worship service has, among others, a pastoral motive and function (Shelling 1989:19; Strydom 1994:193, 289). Strydom (1994) understands this pastoral function as that the worship service is not only the service (diakonia) of the churchgoers but also the service to the churchgoers, where the churchgoers are built up, taught, admonished, encouraged, comforted, strengthened and healed.

Jones (2010:37) goes a step further by saying that music is pastoral work. Jones (2010:37) rightly states that music can comfort, encourage, instruct, teach, proclaim the gospel, interpret Scripture, make application and reach the soul. Routley (1978:94) refers to the 'tiny miracle of healing people through church music'.

Liturgical singing is thus much more than praise and worship; it is also and especially pastoral care. That means that songs are not only sung to glorify God, proclaim the gospel, refute heresy, et cetera, but songs are sung also to encourage one another, help one another and in this context to contribute to healing (the latter is described and discussed in the section on Healing: Insights from pastoral therapy).

\section{Singing within a postmodern paradigm}

Within the postmodern worldview, art, symbolism, metaphors, rituals and music (and by implication singing) can play a role in the process of healing (Maritz \& Dreyer 2002:1268). ${ }^{1}$ Poetry, metaphors, symbols, art and music can contribute to a meeting with God in a context where words and techniques fail to do that (Dingemans 1991:146; Maritz \& Dreyer 2002:1272). Music has the ability to address both the rational and emotional qualities of being (Maritz \& Dreyer 2001:1268).

The influence of postmodernism led to a new realisation of the importance of art and therefore also music. It is also worthwhile to note that younger generations tend to move to churches and denominations where among others they sing more and experience more in their singing. Postmodernism is more open to emotions and feelings, and younger people tend to move to places of worship where singing and music is more than a cognitive confession. Maritz and Dreyer (2001:1279) rightly remark that the holistic thoughts of the postmodern era, as well as the rise of music therapy in the past 60 years, contributed to a new appreciation of the essence of music for humans. There is a growing awareness of the therapeutic power of music in medicine as well as in other therapies.

One can hardly imagine a worship service without congregational singing. Müller (1990:36) rightly remarks that we sing because we are human and we sing because we are believers. Singing is part of human communication and part of religious communication and therefore part of the worship service. Music is a gift of God in helping us to deal creatively with God, reality, ourselves and other people (Maritz \& Dreyer 2001:1266).

Kloppers (1997:208-209) and Pieterse (1993) remark that music within the context of liturgy as communicative acts provides an opportunity for ruler free communication. Within the epistemological frame of reference of postmodernism, Kloppers indicates relations between metaphorical theology, church music, doxology and communicative acts.

\section{Pastoral function of liturgy and liturgical singing}

One of the functions of hymnology is to define the purpose and aim of liturgical singing, as well as the liturgical function(s) of music (Strydom 1987:45). Liturgical singing and music has a definite purpose and is much more than

1.Eric Clapton, composer of Tears in Heaven, tells about the tragic years after 1990: 'In August 1990, his manager and two of his roadies (along with fellow musician Stevie Ray Vaughan) were killed in a helicopter accident. Seven months later, on March 20, 1991, Clapton's four-year-old son Conor died after falling from the 53rd-floo window of his mother's friend's New York City apartment. He landed on the roof of an adjacent four-story building. After isolating himself for a period, Clapton began working again, writing music for a movie about drug addiction called Rush. Clapton working again, writing music for a movie about drug addiction called Rush. Clapton dealt with the grief of his son's death by co-writing "Tears in Heaven" with Will Jennings. A live performance of the song appears on Clapton's 1992 Unplugged. Unplugged topped charts and was nominated for nine Grammy Awards the year it was released. Clapton made numerous public service announcements to rais awareness for childproofing windows and staircases ... In an interview with Daphn Barak, Clapton stated, "I almost subconsciously used music for myself as a healing agent, and lo and behold, it worked.... I have got a great deal of happiness and a great deal of healing from music"' (Wikipedia n.d.[a]). 
filling the gaps or drawing people closer or creating the right atmosphere for the preaching as is often done (Strydom 1994:285). Liturgical singing has definite pastoral functions. Barnard (1981:350-351) identifies various functions of liturgical singing; the following need to be mentioned within the scope of this study (my translation): lamentation and struggle, question and petition, liberation and joy, thoughts and understanding, belief and confession and worship and praise. Thus, liturgy ought to create space for lamentation, struggle, question, petition, liberation, joy, trying-tounderstand, etc. In liturgical singing not only the answers formulated in the course of centuries must be heard, but liturgical singing must also verbalise question, seeking, longing, fear, lament, not-understanding and woundedness (Duck 2013:240).

Schelling (1989:108) emphasises the role of liturgical music in the expression of emotion, in prayer and in times of mourning. Within a growing movement of praise and worship, liturgical singing is often reduced to two components, namely praise and worship. Elements like lamentation, struggle, mourning and question are often absent in the worship service - mostly because of the contemporary view of praise and worship. Cilliers (2009b) rightly asks:

$[D]$ o they (the worship services) also create spaces where we can lament over experiences of contingency, refusing to gloss over the conflict and suffering in this world (thus acknowledging that we are still in a process of 'becoming')? (p. 24)

\section{Arbuckle (1991) summarises:}

This is a thoroughly pathetic and frightening picture of a deathdenying culture, for just as we seek to deny physical death, so also we are apt to ignore all kinds of painful personal and social loss. We have developed a pervasive mythology in which success is the hallmark of Western identity and failure or loss has no place in it. (p. 44)

Liturgical music can only have a healing function and purpose when the pastoral function of liturgical singing and music is re-discovered, creating space for lament, benediction, confession, etc. This function and the aim of liturgical singing are greatly ignored (see Duck 2013:231) within the normal worship service (with the unhealthy emphasis on the praiseworship scheme), mainly because of ignorance (lack of knowledge) or a disconnectedness with the events of normal life. Calitz (2011:342) indicated through an empirical study how congregations tend to follow a worship order without considering the context and day-to-day life of the congregation or community that attends the worship service. ${ }^{2}$

\section{Healing: Insights from pastoral therapy}

The insights from pastoral therapy could be of great value in the discussion of the pastoral function of liturgy. Pastoral liturgy suggests among others that liturgy (and liturgical singing) should mediate and contribute to healing through a

\footnotetext{
2.1 attended a worship service where an older man collapsed during the worship service. A few men took him out and to hospital. The liturgist just went on as if nothing happened; he did not even stop for few seconds to pray for the sick member.
}

process of liturgical pastoral care. Firet (1977) refers to the hermeneutical moment and the agogic moment, indicating a moment of understanding and a moment of change (see also Duck 2013:235). Thus, as pastoral therapy ${ }^{3}$ aims at change ${ }^{4}$ (healing), so does liturgy (in its pastoral function) aim at change and healing. More people will come to a worship service for healing than would go to the pastor and other helpers during the week. Thus liturgy remains one of the most important means of pastoral counselling for the majority of church members and visitors.

Louw (2009:132) identifies five basic viruses that endanger and intoxicate spiritual health and can rob human life from meaning, namely anxiety, guilt, despair and doubt, helplessness and vulnerability, and frustration and disillusionment. These are the issues Christians as churchgoers deal with every day. The average churchgoer will often experience one or more of these emotions in the course of every year, and certainly within many worship services. Louw (2009:133) rightly states that practical theological ecclesiology (and by implication liturgy) should be engaged in these life issues in such a way that it contributes to change and healing and also to meaning and hope. The aim of pastoral therapy is also (on a smaller scale) the aim of liturgy with regard to the pastoral function of liturgy, namely to advance the partaker in liturgy to a state of healing, change and growth by communicating the gospel of Jesus Christ (Louw 1997:28; Maritz \& Dreyer 2001:1268). Liturgy (with a pastoral aim) wants to facilitate a meeting between the churchgoer (within his or her situation) and God (Maritz \& Dreyer 2001:1270).

\section{Louw (2009) rightly says:}

Spiritual healing occurs when the content of the Christian faith is related to the above mentioned existential issues in such a way that hope and meaning is discovered and introduced. Healing does not imply that all the problems of life are being solved, but how one understands God and relates one's God-image to life in order to live the problems in an appropriate and responsible way. Spiritual healing occurs when one can relate an appropriate understanding of God to the basic issues in life. Healing is about the encounter between life and God and the quality of our being functions which emanates from such an encounter, as well as an awareness of the presence of God (the Coram Deo principle) that inspires and motivates faith. (p. 135)

It is often not so easy to 'measure' healing and to know whether somebody has been healed. How can healing be described? Louw (1997:79) considers healing as the central point of pastoral care. He then distinguishes between salvation (heil) and healing (heling) (see also Coetzer 2013: 23-24). He understands pastoral therapy as a process of change because of a process of growing in understanding, which leads to healing (Maritz \& Dreyer 2001:1275). Pastoral therapy ${ }^{5}$ aims at facilitating a meeting or confrontation with

3.Louw (1997:28) describes the aim of pastoral therapy as contributing to a state of healing, change and growth through the communication of the gospel.

4.The crucial moment in therapy is change (Maritz \& Dreyer 2001:1273).

5.Pastoral therapy could be defined as faith help leading to life help (Louw 1997:58). 
God (Maritz \& Dreyer 2001:1270). Within this meeting the believer meets God who has compassion for him or her amidst their crisis. Most often healing will come through a process of learning more about God, life and God's intention for us, in other words reframing our pictures of God and life.

At the end the aim of pastoral therapy is doxology; coming to a new or even better praise of God. Doxology in this sense does not only refer to songs of praise, but also (and especially) a life of praises to God. In the words of Luther it could be described as a life to the glory of God (Coram Deo). Healing within a congregation after a disaster or tragedy would then imply the process of coming to understanding and starting anew to live a life of praise Coram Deo:

The real and most fundamental healing of life occurs when a person experiences intimacy (Geborgenheit); that is, to be accepted unconditionally for whom you are, without the fear of being rejected. (Louw 2009:136)

Brueggemann (in Kloppers 1997:164) sees doxology as an act of hope which 'promises and anticipates a hoped-for world that is beyond present reality'. Doxology therefore does not only contain words or lyrics of praise but also silence, amazement and an awareness of awe (Maritz \& Dreyer 2001:1274).

\section{Music: Insights from pastoral therapy}

The insights from pastoral therapy could be of great help in the understanding of music within liturgy, with special reference to the pastoral and healing function of music. In this regard, one has to distinguish between music as therapy and music in therapy (Maritz \& Dreyer 2002:1210; Van Schalkwyk 1998:24). Music in therapy implies that music is not the main therapeutic agent in the process, and the patient is not actively involved in the music. Music prepares the atmosphere for the meeting or care. Music as therapy, on the other hand, implies that music is an important therapeutic agent, and the patient is actively involved in the activity of music and music-making. Müller (1990:42) refers to the communicative nature of the worship service where music (and singing) communicates not only on the cognitive level but also on the level of experience.

Within the worship service, music could thus have both functions. On the one hand music could be used (as is often done) in the background in preparing the atmosphere of or for the worship service. On the other hand, especially where people partake in the music through playing instruments or singing actively with other members to the music, they become actively involved in the activity of music-making. Campbell (1997:209) states that ' $[\mathrm{m}]$ usic helps in the ritual of release, allowing us to let go of our emotions, and to grieve'. In this regard Campbell (1997:90) says 'I tone, therefore I am!', emphasising that the human voice is the most appropriate and available instrument for healing. Thus, through singing in the worship service (music as therapy), the congregation becomes actively involved in the activity of music-making and ultimately the process of healing.
Storr (1992:90) rightly emphasises the ability of music to uplift the listener beyond their own reality. The latter underlines Long's (2001:53) emphasis on the importance of congregational singing in the worship service.

Schelling (1989:81) adds that the lack of music and play says more than a thousand words, emphasising that there are moments when a congregation lacks words or lyrics to express their sorrow (Maritz \& Dreyer 2001:1284). In a situation like this the silence says more than the lyrics. Psalm 137 could be mentioned in this regard. Thus, although music and singing is very important in the process of lamenting and eventually healing, there are moments when music must fade.

Music within the worship service could have among others the following functions:

- To bring to the surface forgotten experiences and also unprocessed experiences (Schelling 1989:83).

- To bring about a catharsis (Schelling 1989:80). Schelling illustrates how people in the Bible emptied themselves through music and singing (see David and Jeremiah) and then continued with their lives.

- Music, as ordered sound, could help in the ordering of thoughts and cognitive processes. Peters (1987:51) says that ' $[t]$ he order and structure present in music, especially in its rhythm can help an individual organize his or her own perceptive world'.

\section{Liminal liturgy (liturgy of transition)}

A last perspective that could be of great value in the conversation of healing liturgy (or the pastoral aim of liturgy) is the insights on liminal liturgy, implying liturgy in a period of transition or liturgy in an in-between period. Cilliers (2009a:169) refers to liturgy between home and the destination. Liminality supposes a period of steadiness, followed by a dramatic change leading to a phase of liminality, and hopefully arriving at a new destination.

Within the liminal space, Cilliers (2009a:169-171) distinguishes a time of lament (tomb), a time of reframing (wilderness) and a time of anticipation (exile). It is important to create liturgical spaces for lament within the liminal liturgy (Cilliers 2009a:173). Reframing includes a process of rethinking and reframing shattered God-images (Cilliers 2009a:174). 'This called for the rearrangement and reappropriation of their religious beliefs, and ultimately a reimagination and renaming of their God-images' (Cilliers 2009a:174-175). Anticipation appreciates the tension between not yet and already - not jumping to the already, thus anticipation and hope; celebration of the future that is to come (Cilliers 2009a:175, 2009b:21-25).

Congregations who experience loss or tragedy often enter a liminal space where they move from a certain point or state (where they remained for a long time and usually felt at comfort) to another state which is mostly unknown. In this 
period they move through the phases Cilliers indicates above. A liminal liturgy or liturgy of transition is needed for such a liminal period. A liminal liturgy will therefore make space (within liturgy) for lament, reframing and participation. If done effectively, liminal liturgy could contribute to the process of healing. Music could be of great help in the processes of lament, reframing and participation.

\section{Autoethnographic study}

The empirical part of this study is conducted by means of an autoethnography as indicated in the Introduction to this study. We start by describing ethnography followed by a description of autoethnography.

Ethnography is a means of collecting data through participating observation. It admits that the researcher is also subjectively engaged in his or her research, and that total objectivity is impossible. It is less concerned with the facts and truths of theories (claiming to be totally objective) and more concerned with narratives and stories, thus closer to literature than to physics (Ellis, Adams \& Bochner 2011). The researcher uses interviews and participating observation to collect data (Wepener 2012:2). The researcher collects data, reports about the data and evaluates the data:

Many of these scholars turned to autoethnography because they were seeking a positive response to critiques of canonical ideas about what research is and how research should be done. In particular, they wanted to concentrate on ways of producing meaningful, accessible, and evocative research grounded in personal experience, research that would sensitize readers to issues of identity politics, to experiences shrouded in silence, and to forms of representation that deepen our capacity to empathize with people who are different from us. (Ellis et al. 2011:n.p.)

Autoethnography is a further development of ethnography where the researcher is at the same time subject and object of the research. Wepener (2012) describes it as follows:

Outoetnografie word dikwels gebruik as 'n soort kortpad wanneer die tyd en fondse vir ' $n$ volwaardige etnografiese studie wat maande en selfs jare behoort te duur, ontbreek en fokus dikwels op ' $n$ waarneming en noukeurige dokumentering van die navorser se eie gedrag. (bl. 2)

The researcher recognises the innumerable ways personal experience influences the research process. Ellis et al. (2011:n.p.) rightly remark that 'autoethnography is one of the approaches that acknowledges and accommodates subjectivity, emotionality, and the researcher's influence on research, rather than hiding from these matters or assuming they don't exist'. As such the autoethnographic study will take into consideration observations, emotions and experiences in the process of research:

Autoethnography is an approach to research and writing that seeks to describe and systematically analyze personal experience in order to understand cultural experience. This approach challenges canonical ways of doing research and representing others and treats research as a political, socially-just and sociallyconscious act. A researcher uses tenets of autobiography and ethnography to do and write autoethnography. Thus, as a method, autoethnography is both process and product. (Ellis et al. 2011:n.p. [abstract])

\section{Description of process of loss \\ Congregation who lost a beloved pastor}

The grieving congregation is an urban Dutch Reformed congregation with 900 adults and 200 children, situated in Potchefstroom, South Africa. The congregation was served by two full-time pastors where Pastor A was serving for the last 25 years and Pastor B (myself) for the last 18 years. In May 2013 Pastor A (52 years old) suddenly became very ill and died on 15 May 2013. The word trauma ${ }^{6}$ (Oxford n.d.; Coetzer 2013:32) helps in describing the experience of this congregation.

On 06 May 2013 (the day on which the blood clot went through Pastor A's lungs) the doctor called the family and friends and briefed them on the situation. His words still echoes today: from a human point of view, nothing can be done to save Pastor A's life. On that day, the congregation moved into a liminal space, suggesting all the processes of lamenting, reframing and anticipation. It can also be described as a pre-impact phase which is a phase where people prepare for a possible crisis (Coetzer 2013:39).

\section{Prayer meeting on 06 May}

That evening the congregation came together (on short notice) to pray for Pastor A. Pastor B and the music director decided to share the news the doctor gave, sing three songs and pray for Pastor A. After the congregation was briefed on the situation, they sang a song (Heer, $U$ is my lewe $e^{7}$ that was very precious for Pastor $\mathrm{A}$ as well as the congregation and thus associated with Pastor A:
Heer $U$ is my lewe, my krag en my vrede
by $\mathrm{U}$ kan ek rustigheid vind.
In $\mathrm{U}$ is verlossing en krag tot oorwinning
in $\mathrm{U}$ kan ek vrede vind.
Kom vul my o Here met liefde en vrede
kom vul my o Heilige Gees
Kom lei my en leer my, besit my, beheer my,
gebruik my o Heilige Gees.
[Lord You are my life, my strength and my peace
in You I can find tranquillity
In you are deliverance and the power to victory
in You I can find peace.
Come fill me, oh Lord, with love and peace
come fill me o Holy Spirit
Lead me and teach me, have me and control me
use me Holy Spirit] (unpublished, [own translation])

The song was sung for two reasons: firstly, because it was precious to Pastor A (thus a form of remembering), and it was a prayer for God's peace and strength - a song that was often sung in times of tribulation in the congregation.

6.A deeply distressing or disturbing experience or emotional shock following a stressful event or a physical injury, which may lead to long-term neurosis (Oxford n.d.).
stressful

7.Unpublished free song written by Erna Rheeder. 
While singing the song, church members started crying uncontrollably. The sound of people crying and lamenting mixed with the sound of piano and voices. The song led to a sort of catharsis for all the emotions inside which were building up in the last few days of Pastor A's hospitalisation as the situation worsened every day. The other two songs were not sung as planned, mainly because of the intense emotions at that moment. The congregation went into prayer whereafter they spent some time (lamenting) in the church building. Schelling (1989:81) remarks in this regard 'het ontbreken van zang en spel zegt meer dan duizend woorden'.

The next week, on 15 May 2013, Pastor A died in hospital (Coetzer 2013:39 on impact phase, the phase where the trauma occurs). This came as a great shock to the congregation, as they kept believing that God will intervene and heal their pastor. The congregation entered a liminal phase, which supposed a phase of lamenting, reframing and participation. It was a time of much visible emotions: shock, grief, anger, questioning and loss.

\section{Memorial service}

The memorial service was held on 18 May 2013 and attended by hundreds of people. The memorial service was led by another colleague from another congregation.

The family chose two secular songs that were special to them to be played during the worship service. The first song was a song by Snotkop ${ }^{8}$ with the title Song vir my dad [Song for my dad]. This song was chosen by Pastor A's four children and combined with photos of them with their dad. The song is about the singer (Snotkop) singing to his dad and telling him that he loves him and he is proud of him (his dad). The other song was Love changes everything, ${ }^{9}$ a song often played by Pastor A during times of offerings in the liturgy and which (in time) became one of the songs associated with Pastor A. This song was chosen by his wife and combined with photos of them. These two songs with the photos were used in remembrance of him, picturing some of the highlights in their lives. But with the remembrance, these two songs had a huge catharsis effect at the beginning of the memorial service. Attendees cried and mourned visibly.

During the memorial service, three songs (chosen by the family) were sung by the whole congregation: Wat ' $n$ vriend het ons in Jesus (What a friend we have in Jesus ${ }^{10}$ - old Hallelujah song); Heer, $U$ is my lewe [Lord you are my life ${ }^{11}$ ] the same song sung during the prayer meeting on 06 May, and Wees stil en weet [Be still and know that I am God ${ }^{12}$. The first song is an old hymn to comfort, the second song a song of trust and the third song a song encouraging one to be silent and remember that he is God.

8.Performing name of South African singer/artist Francois Henning (Wikipedia n.d.[b]).

9.A song from the musical Aspects of Love, composed by Andrew Lloyd Webber, with a lyric written by Charles Hart and Don Black (Wikipedia n.d. [c]).

10.Written by JM Scriven in 1855 as a song of comfort (Wikipedia n.d.[d]).

11.Free song written by Erna Rheeder.

12.Words: Anonymous, based on Psalm 46.

\section{Morning service on 19 May}

During the morning service on 19 May, the Holy Communion was celebrated, although the atmosphere was everything but celebration. The theme for the worship service was scars. The liturgist first reflected on everything that happened in the previous week (which was a very difficult week), whereafter the congregation sang three songs: Kom, o Skeppergees [Come, Spirit of the Creator], O Heilige Gees ons Trooster gestuur [Oh Holy Spirit, our Comforter] and Gees van God wat in my woon (Afrikaans translation of Spirit of the living God). These songs are mostly songs of prayer (not praise) and contain phrases like bring tranquillity in my mind; give me peace; comfort me; et cetera. The reading came from Luke 24 and the theme was: Scars. Jesus went back to his father with scars in his hands and body. He took our scars to heaven. Heaven contains scars. Jesus was a wounded healer; we are also wounded healers. With this, the congregation remembered their own scars (brokenness) at that very moment. The congregation then sang Ons is gewone mense, Here ${ }^{13}$ [We are only ordinary people, Lord, jars of clay that break so easily], a song based on 2 Corinthians 5 . In this song the congregation remembered and confessed their brokenness. The Holy Communion was celebrated, remembering that we worship a God with wounds. Coetzer (2013:128-129) emphasises the importance of the Holy Communion in the process of healing. During the offerings, pencil sketches of Jesus with the theme Always with you (done by Larry von Pelt) were displayed; these were combined with an English contemporary song Open our eyes, Lord. ${ }^{14}$ The song emphasised that God is with us no matter what. The worship service was concluded with an old hymn: O, Heer, my God [Oh Lord, my God ${ }^{15}$. The last verse anticipates the day when Jesus will come back and make everything whole:

$\mathrm{U}$ maak ons deel van al $\mathrm{u}$ grootse werke.

$\mathrm{U}$ laat ons bid, Heer, dat u ryk mag kom.

En kom U weer, in heerlikheid op wolke, maak U volkome nuut $\mathrm{u}$ eiendom.

[You make us part of all your great works.

You let us pray, Lord, that you kingdom may come.

And when you come again in glory on the clouds

You make your property completely new.] (NG Kerk 2001, [own translation])

It must be noted that the order of liturgy changed from sorrow and lament to anticipation and looking forward to the second coming of Jesus when everything will be new and whole.

\section{Morning service on 26 May}

The theme for the morning service on 26 May was broken hallelujah's. The well-known song of Leonard Cohen $\left(\right.$ Hallelujah $^{16}$ ) was played in the 5-min slot before the start of 13.Written by Andries Celliers (unpublished).

14.Written by Bob Cull (Songselect n.d.).

15.A Christian hymn based on a Swedish traditional melody and a poem written by Carl Gustav Boberg (1859-1940) (Wikipedia n.d.[e])

16.A song written by Canadian recording artist Leonard Cohen, originally released on his album Various Positions (1984) (Wikipedia n.d.[f]). 
the worship service (thus music in therapy). This time the congregation started with praise and sang two songs of praise: U goedertierenheid [Your mercy] and Jesus roep verlore sondaars [Jesus calls lost sinners], remembering that we have only a few chords and a few instruments to praise God; our praises are broken. The congregation could literally feel the brokenness in their songs of praises, as it remained in the minor tone. These were followed by two more songs: Wonderbare Koning ${ }^{17}$ [Wonderful King] and Kom dank nou almal God [Come all, come thank God!18]. Again the congregation was reminded that we have such limited sources (voices and instruments) with which we can praise God; therefore, our praises are broken. After reading Psalm 42 , the congregation listened in silent prayer to a new version of Psalm 42 as composed by Louis Brittz (thus music in therapy). The theme of the preaching was Broken Hallelujah's. The congregation listened to the song of Leonard Cohen (Hallelujah) while following the lyrics on the screen. Cohen sings about King David who sang a perfect Hallelujah to God. After his sin with Beersheba, he only had a broken hallelujah. Through the narrative of David the Hallelujah becomes more and more a broken hallelujah:

\author{
I've heard there was a secret chord \\ That David played, and it pleased the Lord \\ But you don't really care for music, do you? \\ It goes like this \\ The fourth, the fifth \\ The minor fall, the major lift \\ The baffled king composing Hallelujah \\ Hallelujah, Hallelujah \\ Hallelujah, Hallelujah \\ Maybe there's a God above \\ But all I've ever learned from love \\ Was how to shoot at someone who outdrew you \\ It's not a cry you can hear at night \\ It's not somebody who has seen the light \\ It's a cold and it's a broken Hallelujah \\ Hallelujah, Hallelujah \\ Hallelujah, Hallelujah (Cohen 1992, [own emphasis])
}

Christians often experience broken hallelujah's, because of things that happened in their lives. The liturgist explained that the congregation (in this phase of lament) has a broken hallelujah, like God's people in Psalm 137 and the psalmist in Psalm 42. The congregation then joined in three songs, all expressing some form of lament and worship: Ons is gewone mens, Here ${ }^{19}$ [We are only ordinary people, Lord, jars of clay that break so easily]; Lei U ons lig ${ }^{20}$ [You are our light - please lead us]; and Lofofferlied ${ }^{21}$ [Offer of praise song]. The service was concluded with a song of anticipation Die wat die Here wil dien [Those who want to serve the Lord ... they have a new future], looking forward to God's new future:

Dié wat die Here wil dien,

17.From the German song: Wunderbarer König (written by Joacim Neander 1680).

18.From the German song: Nun danket alle Gott (written by Johann Krüger 1648).

19.Written by Andries Celliers (unpublished).

20.Translation of song written by Henry Newman 1834.

21.From the English song 'In moments like these' (author unknown). hul het 'n nuwe toekoms

swaarkry vir altyd verby -

God laat hul vreugde sien.

Stil maar, wag maar, alles word nuut -

die hemel en die aarde.

Stil maar, wag maar, alles word nuut -

die hemel en die aarde!

[Those who want to serve the Lord,

they have a new future

hardships gone forever -

God will see their joy.

Hush, wait, everything is new -

the heavens and the earth.

Hush, wait, everything is new -

the heavens and the earth!] (NG Kerk 2001, [own translation])

While exiting the building, a song of blessing Die Heer sal jou beskerm [The Lord will protect you] was played. It must be noted that the tone of the preaching was lament while the service again concluded in a tone of anticipation, remembering that God will make everything new.

\section{Evening service on 26 May}

The evening service on 26 May was led by a liturgist from another congregation who became involved in the congregation during the days after the death of Pastor A. The reading came from Romans 5:1-5 and the theme of the preaching was that the Triune God breaks into our (broken) world. The concluding song came from Liedboek van die Kerk 449:1-4. The song includes the following phrases:

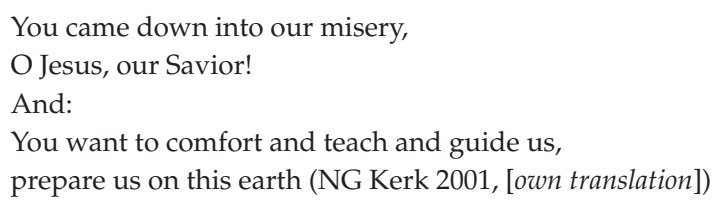

Apart from all the songs sung (mainly worship and not praise), the liturgist used another secular song of Leonard Cohen with the title Anthem. The refrain of this song contains these words:
Ring the bells that still can ring
Forget your perfect offering
There is a crack in everything
That's how the light gets in ... (Cohen 1992)

The congregation was reminded that we live in a broken world and that God's light shines through the cracks of this broken world. This song was used as music as therapy, actively engaging the churchgoers in active listening and explaining the song.

\section{Morning worship service on 02 June}

The theme of the morning worship service was Life and health. The worship service was preceded by an audiovisual display of the song Net $U^{22}$ [Only You], emphasising the power and sovereignty of God, who cares for his creation. The intention of the worship service was to move forward one small step and celebrate life. The worship service started with praise 22.Afrikaans gospel song by Charl Botha. 
and concluded with anticipation. The songs of praise included the following: Hy laat die sterre skitter (Afrikaans translation of he made the stars to shine); Prys die Here van die aarde af [Praise the lord from the earth]; O Heer my God [How great Thou art]; and $U$ liefdeslied vir $m y^{23}$ [Your lovesong for me]. The latter is a song of praise celebrating life as well as the new life Jesus brought. After the baptism of an infant, the congregation sang three songs of worship: Kom buig daar in aanbidding [Oh come let us adore him]; Lord I lift your name; and Heilig, heilig, heilig [Holy, holy, holy]. The reading came from Matthew 8:1-4 and the theme of the preaching was: The missing link? The preaching and the whole service was an attempt to reframe: Does God still heal people? Why didn't he heal Pastor A? Is there something that the congregation could have done to convince God to heal? Among others, the answer was partially found in Matthew 8:1-4: 'If you want, You can heal me'. He decides when to heal and when not to heal. God is sovereign - we do not understand his will and his ways. During the offerings, the congregation watched an audiovisual presentation of The gentle healer by Michael Card. The worship service was then concluded with the singing of an old hymn: Because he lives, ${ }^{24}$ reminding ourselves that Jesus lives and reigns with the Father. Even when we are not healed, there is a great future for God's children.

\section{Remarks on the worship services}

After the death of Pastor A, the congregation entered a liminal phase or period. Their beloved pastor was dead and the structures they knew for at least 25 years had collapsed. Church members experienced loss and grief. The congregation had many questions about death and God. The worship service became the prominent space for joined grief - the place where (for the next few weeks) congregation members will come weekly to mourn and revisit the trauma of the last few weeks. Coetzer (2013:132-134) stresses in this regard the importance of re-telling the stories and re-visiting the trauma.

Because the congregation entered a phase of grief, the songs of praise were scaled down. Even when songs of praise were sung, they lacked the joy usually experienced in these songs. Songs of lament were used instead; also songs of worship and songs of rephrasing (Cilliers 2009b:4-5). The normal order of the worship service changed to an order of lament, rephrasing and anticipation. All the songs, including the songs of praise, became broken hallelujah's sung in a muted tone. Songs with strong associations to Pastor A were mostly omitted from the worship service. The worship services and especially the singing were characterised by mourning. Tears and crying became part of every Sunday's singing. In a certain sense, the congregational singing had a catharsis effect (Schelling 1989:80) and brought the emotions of loss to the fore. Songs in liturgy were chosen to convey a rational understanding as well as an emotional experience.

Music and singing functioned in two ways: music in therapy and music as therapy. The songs the congregation listened to

23.Contemporary Afrikaans song written by Louis Brittz.

24.English hymn written by Bill and Gloria Gaither. during these worship services could be described as music in therapy. The congregation did not actively take part in the music by singing or making music. The congregation were active in the sense that they followed the lyrics on the screen. Although there are studies that focus on active music listening (Kleynhans 2006), it is still music in therapy. These included Song vir my dad, Love changes everything, The gentle healer, Anthem, Hallelujah, Open our eyes Lord, et cetera.

Music was also used in the sense of music as therapy. Besides all the members involved in the music-making, the whole congregation took part in the congregational singing. The songs sung included songs of praise, lament, worship, benediction, reframing, participation, etc. The singing and music facilitated a catharsis for all the emotions of grief, anger, aggression, depression, disappointment, et cetera. The congregational singing intended to ask, understand, reframe, encourage and so forth.

Silence within the worship service became a very important moment. The singing was often followed by silent prayer where every member could reflect, ask, pray and anticipate (Schelling 1989:81).

This pattern was followed for May, June and a part of July of 2013. On the first Sunday of the new quarter, after 2 months of lament, the congregation grew to a point where they were able to sing songs of praise without crying. The muted tone in the worship service, as well as in the congregation itself, was replaced by a new enthusiasm for the future. Congregation members started looking and living ahead again, while not forgetting the past. Less lament and tears could be observed during the worship service. The congregation experienced healing, returning to more songs and lives of doxology (Louw 2009:15). The hermeneutical moment was supplemented by an agogic moment (Firet 1977). In the process of reading and interpreting the Word, the congregation experienced healing. Music and singing played a definite role in the process of healing.

\section{Conclusion}

The role of music and singing in the worship service is often underestimated. By reducing congregational singing to mere praise and worship, the pastoral function and aim of liturgy, and especially music and singing in liturgy, are largely neglected. A careful selection of songs from the unique repertoire of songs in a congregation can contribute to healing (Routley 1978:94). Not only congregational singing (music as therapy) but also active or passive listening to music (music in therapy) could be of great value in the process of healing.

This also calls for a new view on the worship service. Liturgy in the worship service must be closely related to the day-today life of the congregation. A liturgy that only includes the major narrative (the Bible) without taking seriously the smaller narrative (the life and story of the congregation) fails in being pastoral. A liturgy that includes the smaller narratives, but remains silent about the major narrative, can 
never lead to a hermeneutical and agogic moment. A healing liturgy always includes the major narrative and the smaller narrative. Pastoral liturgical singing does not only praise and worship; it also laments, asks, protests, mourns and keeps silent.

With Maritz and Dreyer (2001:1285) I conclude that the challenge in a new era with new possibilities is to (again) make music part of our experience and sense-making of reality so that we can live as whole humans glorifying God.

\section{Acknowledgements Competing interests}

The author declares that he has no financial or personal relationships that may have inappropriately influenced him in writing this article.

\section{References}

Arbuckle, G.A., 1991, Grieving for change: A spirituality for refounding communities, Cassell, Strand.

Barnard, A.C., 1981, Die erediens, NG Kerkboekhandel, Pretoria.

Calitz, C.J., 2011, 'The free song (hymn) as a means of expression of the spirituality of the local congregation with specific focus on the situation of the Dutch Reformed Church in South-Africa', PhD thesis, Department of Theology, University of Pretoria.

Campbell, D., 1997, The Mozart effect: Tapping the power of music to heal the body, strengthen the mind and unlock the creative spirit, Avon Books, New York.

Cilliers, J., 2009a, "Worshipping in the "in-between" times of transition: Reflections on the liminality of liturgy', in H.J.C. Pieterse \& C.H. Thesnaar (eds.), A faithful witness, pp. 167-179, Bible Media, Wellington.

Cilliers, J., 2009b, 'Why worship? Revisiting a fundamental liturgical question', HTS Teologiese Studies/Theological Studies 65(1), Art. \#126, 1-6. https://doi.org/ 10.4102/hts.v65i1.126

Clapton, E., n.d., Tears in heaven, viewed on 18 April 2015, from http://en.wikipedia. org/wiki/Tears_in_Heaven

Coetzer, W., 2013, Trauma - die meedoënlose vyand, PTP, Potchefstroom.

Cohen, L., 1992, Anthem, Anthem lyrics (C) Sony/ATV Music Publishing LLC.

Dingemans, G.D.J., 1991, Als hoorder onder de hoorders, Kok, Kampen.

Duck, R.C., 2013, Worship for the whole people of God, John Knox Press, Westminister.

Ellis, C., Adams, T.E. \& Bochner, A.P., 2011, 'Autoethnography: An overview', Forum Qualitative Sozialforschung/Forum: Qualitative Social Research [S.I.], 12(1), nov. 2010, viewed 21 April 2016, from http://www.qualitative-research.net/index. $\mathrm{php/fqs/article/view/1589/3095}$

Firet, J., 1977, Het agogisch moment in het pastoraal optreden, Kok, Kampen.

Horness, J., 2004, 'Contemporary music-driven worship', in P.A. Basden (ed.), Exploring the worship spectrum, pp. 99-116, Zondervan, Grand Rapids, MI.

Jones, P.S., 2010, What is worship music? P \& R Publishing, Phillipsburg, NJ.

Kleynhans, C.T., 2006, 'Aktiewe musiekbeluistering as verryking en vernuwing van die erediens', MTh-verhandeling, Universiteit van Pretoria.

Kloppers, E.C., 1997, 'Liturgiese musiek as kommunikatiewe handeling in 'n postmodeme era', DTh-proefskrif, Universiteit van Suid-Afrika.

Long, T.G., 2001, Beyond the worship wars: Building vital and faithful worship, Alban Institute, Bethesda, MD.
Louw, D., 2009, 'Please quit your God! Intoxication in Christian spirituality and the healing dimension within an existential approach to a practical theological ecclesiology', in H.J.C. Pieterse \& C.H. Thesnaar (eds.), A faithful witness, ecclesiology, in H.J.C. Pieterse \& C.H.
pp. 125-137, Bible Media, Wellington.

Louw, D.J., 1997, Pastoraat as ontmoeting en vertolking, Lux Verbi, Pretoria.

Louw, J.P. \& Nida, E.A., 1989, Greek-English lexicon of the New Testament. Based on symantic domains. vol. 1 \& 2, 2nd edn., United Bible Societies, New York.

Maritz, J.F. \& Dreyer, T.F.J., 2001, 'Musiek as hulpmiddel in pastorale terapie', HTS Teologiese Studies 57(3\&4), 1265-1287. https://doi.org/10.4102/hts.v57i3/4.1892

Maritz, J.F. \& Dreyer, T.F.J., 2002, "n Ondersoek na die aanwending van musiek as hulpmiddel in pastorale terapie binne 'n gespreksmodel', HTS Teologiese Studies/ Theological Studies 58(3), 1208-1220. https://doi.org/10.4102/hts.v58i3.595

Müller, J., 1990, Die erediens as fees, NG Boekhandel (Edms) Bpk, Halfway House, Johannesburg.

NG Kerk, 2001, Liedboek van die Kerk vir gebruik by die erediens en ander byeenkomste, 2001, NG Kerk-Uitgewers, Kaapstad.

Oxford Living Dictionaries, n.d., viewed 14 November 2016, from https://en. oxforddictionaries.com/definition/trauma

Peters, J.S., 1987, Music therapy: An introduction, Charles C Thomas Publisher, Springfield, IL.

Pieterse, H.J.C., 1993, Praktiese teologie as kommunikatiewe handelingsteorie, RGNUitgewers, Pretoria.

Pieterse, H.J.C., 2001, Prediking in 'n konteks van armoede, ABC-Press, Pretoria.

Redman, R., 2002, The great worship awakening, Jossey-Bass, San Francisco, CA.

Routley, E., 1978, Church music and the Christian faith, Collins, London.

Schelling, P., 1989, Muziek en Kerkewerk, Uitgeverij Boekencentrum BV, 's-Gravenhage, The Netherlands.

Selander, S.A., 2001, 'Hymnology, aesthetics and religious education: The hymnological-didactical circle', in P. Ballard \& P. Couture (eds.), Creativity, imagination and criticism. The expressive dimension in practical theology, pp. 201-212, Cardiff Academic Press, Cardiff.

Storr, A., 1992, Music and the mind, The Free Press, New York.

Songselect, n.d., Open our eyes, viewed 20 April 2016, from https://us.songselect. com/songs/1572/open-our-eyes

Strydom, W.M.L., 1987, Perspektiewe op die erediens, NG Kerkboekhandel Transvaal, Pretoria, pp. 43-56.

Strydom, W.M.L., 1991, 'Liturgiese sang in diens van die vernuwing van die Gereformeerde erediens', Unpublished DTh dissertation, University of the Orange Free State.

Strydom, W.M.L., 1994, Sing nuwe sange, nuutgebore, NG Sendingpers, Bloemfontein.

Van Schalkwyk, G.J., 1998, " $n$ Sisteemparadigma vir musieksielkunde', Ongepubliseerde PhD proefskrif (Sielkunde), Universiteit van Pretoria.

Wepener, C.J., 2012, 'Wat maak ' $n$ kerkorrel gereformeerd? ' $n$ Verkenning van Afrikaanse "gereformeerde" musiek in die jare 1980 en 1990 in Suid-Afrika', Verbum et Ecclesia 33(1), Art. \#709, 1-8. https://doi.org/10.4102/ve.v33i1.709

Wikipedia, n.d.(a), Tears in heaven, viewed 18 April 2017, from http://en.wikipedia. org/wiki/Tears_in_Heaven

Wikipedia, n.d.(b), Snotkop, viewed 20 April 2016, from https://en.wikipedia.org/ wiki/Snotkop

Wikipedia, n.d.(c), Love changes everything, viewed 20 April 2016, from https://en. wikipedia.org/wiki/Love_Changes_Everything_(song)

Wikipedia, n.d.(d), What a friend we have in Jesus, viewed 06 July 2013, from http:// en.wikipedia.org/wiki/What_A_Friend_We_Have_In_Jesus

Wikipedia, n.d.(e), How great thou art, viewed 20 April 2016, from https://en. wikipedia.org/wiki/How_Great_Thou_Art

Wikipedia, n.d.(f), Hallelujah, viewed 20 April 2016, from https://en.wikipedia.org/ wiki/Hallelujah_(Leonard_Cohen_song)

Wikipedia, n.d.(g), Anthem, viewed 14 November 2016, from https://en.wikipedia. org/wiki/Anthem_(disambiguation)

Wimp, n.d., Best coin ever spent, viewed 18 April 2015, from http://www.wimp.com/ bestcoin/ 